\title{
CANX Gene
}

National Cancer Institute

\section{Source}

National Cancer Institute. CANX Gene. NCI Thesaurus. Code C112099.

This gene plays a role in both protein folding and antigen presentation. 